University of Nebraska - Lincoln

DigitalCommons@University of Nebraska - Lincoln

2006

\title{
Spillover of Agriculturally Subsidized Predators as a Potential Threat to Native Insect Herbivores in Fragmented Landscapes
}

Tatyana A. Rand

University of Nebraska - Lincoln, tatyana.rand@ars.usda.gov

Svata M. Louda

University of Nebraska - Lincoln, slouda1@unl.edu

Follow this and additional works at: https://digitalcommons.unl.edu/bioscifacpub

Part of the Life Sciences Commons

Rand, Tatyana A. and Louda, Svata M., "Spillover of Agriculturally Subsidized Predators as a Potential Threat to Native Insect Herbivores in Fragmented Landscapes" (2006). Faculty Publications in the Biological Sciences. 53.

https://digitalcommons.unl.edu/bioscifacpub/53

This Article is brought to you for free and open access by the Papers in the Biological Sciences at DigitalCommons@University of Nebraska - Lincoln. It has been accepted for inclusion in Faculty Publications in the Biological Sciences by an authorized administrator of DigitalCommons@University of Nebraska - Lincoln. 
Published in Conservation Biology 20: 6 (2006), pp. 1720-1729; doi: 10.1111/j.1523-1739.2006.00507.x

Copyright $@ 2006$ Society for Conservation Biology; published by Wiley-Blackwell. Used by permission.

http://www.wiley.com/bw/journal.asp?ref $=0888-8892$

Submitted September 20, 2005; revised and accepted January 16, 2006; published online July 19, 2006.

\title{
Spillover of Agriculturally Subsidized Predators as a Potential Threat to Native Insect Herbivores in Fragmented Landscapes
}

\author{
Tatyana A. Rand and Svata M. Louda
}

School of Biological Sciences, University of Nebraska, Lincoln, NE 68588-0118, USA

Current address for T. A. Rand - USDA Northern Plains Agricultural Research Laboratory, Sidney, MT; email tatyana.rand@ars.usda.gov

\begin{abstract}
Habitat loss and fragmentation can have strong negative impacts on populations of some native species. Spillover of generalist natural enemies from the surrounding landscape matrix is one mechanism potentially generating such effects, yet this has been rarely studied in insects. We examined the influence of habitat conversion to agriculture on the abundance and potential effects of predatory coccinellid beetles on native insect herbivores within 12 grassland remnants in central Nebraska (U.S.A.). Results of sweep sampling revealed that coccinellids were three to six times more abundant at native grassland sites embedded within cropland-dominated landscapes compared with control sites in grassland-dominated landscapes over the 3 years of the study. Exclusion experiments further demonstrated that predation intensity was strongly related to coccinellid abundances across sites and that coccinellids can dramatically reduce densities of a native aphid herbivore. In contrast to studies of specialized insect parasitoids, which have generally found reduced enemy pressure in fragmented landscapes, our results suggest that native herbivores may in some cases experience increased consumer pressure in landscapes with increasing habitat loss because of spillover of generalist predators from surrounding cropland habitats.
\end{abstract}

Keywords: fragmentation, habitat loss, landscape matrix, spatial subsidies, spillover predation, trophic interactions

\section{El Excedente de Depredadores Subsidiados por la Agricultura como una Amenaza Potencial para los Insecto Herbívoros Nativos en Paisajes Fragmentados}

\section{Resumen}

La pérdida y fragmentación del hábitat puede tener fuertes impactos negativos sobre las poblaciones de algunas especies nativas. El excedente de enemigos generalistas naturales en la matriz circundante es uno de los mecanismos que potencialmente genera tales efectos, pero esto ha sido poco estudiado en insectos. Examinamos la influencia de la conversión de hábitat en agricultura sobre la abundancia y potenciales efectos de escarabajos coccinélidos depredadores sobre insectos herbívoros nativos en 12 remanentes de pastizales en Nebraska central (E. U. A.). Los resultados de muestreos de barrido revelaron que los coccinélidos fueron tres a seis veces más abundantes en sitios con pastizales nativos enclavados en paisajes dominados por cultivos en comparación con sitios control en paisajes dominados por pastizales durante los tres años del estudio. Experimentos de exclusión adicionalmente demostraron que la intensidad de depredación estaba muy relacionada con las abundancias de coccinélidos en todos los sitios y que los coccinélidos pueden reducir dramáticamente las densidades de un áfido herbívoro nativo. En contraste con estudios de insectos parasitoides especializados, que generalmente encuentran presión reducida de enemigos en paisajes fragmentados, nuestros resultados sugieren que, en algunos casos, los herbívoros nativos pueden experimentar mayor presión de consumo en paisajes con incremento en la pérdida de hábitat debido al excedente de depredadores generalistas en los hábitats agrícolas circundantes.

Palabras Clave: depredación excedente, fragmentación, interacciones tróficas, matriz del paisaje, pérdida de hábitat, subsidios espaciales 


\section{Introduction}

The conversion of natural habitat for human use is considered a leading threat to the persistence of native species (Soulé 1986; Saunders et al. 1991; Kareiva et al. 1993) and has become a focal area of research in ecology and conservation. Island biogeographic (MacArthur \& Wilson 1967) and related metapopulation models (Levins 1970) predict that landscape changes associated with habitat loss, such as decreasing area and increasing isolation of natural habitat patches, will result in a decrease in the abundance and diversity of native organisms. Species are likely to differ in their susceptibility to such landscape changes, however, and there is increasing recent interest in understanding the potential implications of such differential responses for food-web dynamics (Holt 1996; Holt et al. 1999).

Theory suggests that organisms occupying higher trophic levels will be more susceptible to extinction in the face of environmental disturbances such as habitat loss than will those occupying lower levels (Pimm 1991; Lawton 1995), particularly in food webs composed primarily of stacked trophic specialists (Holt et al. 1999). The differential loss of higher trophic levels subsequently may result in reduced consumer pressure on resource populations in smaller or more isolated habitat patches (Terborgh et al. 2001; Tscharntke et al. 2002). A number of empirical studies support the prediction that habitat loss and increased patch isolation can reduce the abundance or diversity of insect natural enemies and, ultimately, may disrupt natural-enemy control of herbivore populations (e.g., Kruess \& Tscharntke 1994; Roland \& Taylor 1997; Thies \& Tscharntke 1999). Most of these studies have focused on relatively specialized consumers such as insect parasitoids, which are especially likely to conform to theoretical predictions. However, the response of generalist predators is likely more complex because they may be able to use intervening matrix habitats, a factor expected to obscure the predicted patterns (Holt et al. 1999; Tscharntke \& Kruess 1999).

Despite the traditional use of island biogeography and metapopulation theory as a framework for fragmentation studies, it has long been recognized that unlike islands, terrestrial habitat fragments are not embedded within completely uninhabitable or neutral landscapes. In fact, the surrounding landscape matrix can have an important influence on within-patch dynamics (Vandermeer \& Carvajal 2001; Cook et al. 2002; Jules \& Shahani 2003). The influx of antagonists, such as predators and competitors, from affected matrix habitats is one potential mechanism by which habitat loss can modify ecological interactions, thereby nega- tively affecting resident species within remaining natural areas (e.g., Janzen 1983, 1986; Suarez et al. 1998; Fagan et al. 1999). Additionally, results of theoretical and empirical studies demonstrate that prey present within one habitat type can subsidize mobile consumers, such that they have greater impacts on prey within a second system than would be expected from in situ dynamics alone (Oksanen 1990; Polis et al. 1997; Holt \& Hochberg 2001). Thus, if more generalized predators can take advantage of resource "subsidies" within anthropogenic land-use systems, their abundance and potential impact on prey populations within remaining natural areas may actually increase with habitat loss. This is exactly the opposite of the pattern predicted for specialist natural enemies described above.

Such cross-boundary "spillover" of generalist predators benefiting from the surrounding agricultural matrix, for example, can result in increased avian nest predation or parasitism at forest fragment edges (reviewed in Paton 1994), and it may represent a major threat to the conservation of wildlife populations (Schneider 2001). However, there is a paucity of quantitative data assessing the impact of habitat loss and agricultural intensification on generalist predator-prey interactions for native insect communities in remaining habitat fragments. Consequently, whether or not spillover predation is an important process affecting insect communities within remnant natural areas is unknown.

The importance of the movement of insect natural enemies between natural and cropland habitats is widely acknowledged; however, the emphasis has been almost exclusively on the implications for agroecosystems (e.g., Ekbom et al. 2000). An accumulating body of work demonstrates that resources within surrounding natural habitats can play an important role in driving patterns of natural-enemy abundance, diversity, and impact on herbivorous pests within cropping systems (reviewed in Landis et al. 2000). In contrast, surprisingly little consideration has been given to the potential impact of such shared consumers on the "alternative" prey occurring within the remaining natural habitats themselves. We examined the influence of increasing crop cover in the surrounding landscape matrix on the abundance of a dominant group of generalist insect predators, the coccinellid beetles, within 12 prairie grassland remnants over 3 years. We further carried out a predator-exclusion experiment to assess whether predators affected populations of a native aphid herbivore and whether this effect was related to differences in coccinellid abundance at sites embedded within cropland versus sites within grassland-dominated landscapes. 


\section{Methods}

\section{Site Selection}

The mixed grass prairie of central Nebraska is composed of a mosaic of cropland (primarily corn, soybean, and alfalfa) and natural habitats (primarily prairie grassland/rangeland; Figure 1a). Study sites were areas of prairie grassland $(800 \times 800 \mathrm{~m})$, embedded within a landscape matrix composed of the eight surrounding $800 \times 800 \mathrm{~m}$ land parcels (Figure 1b). We used land-cover data from the National Land Cover Database (U.S. Geological Survey 2000) to select six grassland sites in each of two landscape types: a cropland-dominated matrix (range $=61.1-76.2 \%$ crop cover) and a grassland-dominated matrix (range $=93-100 \%$ grassland cover). To determine cover in each landscape category, we extracted the area of each land-use type within each landscape matrix with Arcview GIS
3.2 (ESRI 1999). For crop percentages, we summed the area of all crop land-use categories (row crops, small grains, alfalfa) within each matrix and divided by the total matrix area. Similarly, grassland estimates were determined by dividing cover of grassland (pasture/ rangeland) by total matrix area. The replicate landscapes within these categories were independent (i.e., nonoverlapping; Figure 1a).

To keep site characteristics as similar as possible, we selected prairie grassland sites that had not been cultivated since at least 1971 and that had similar vegetation structure (percent grass cover, percent forb cover, vegetation height; T.A.R., unpublished data). Additionally, we chose sites that did not significantly differ in major soil traits (water-holding capacity, surface organic matter) and climatic variables (growing degree days, precipitation) between matrix categories (Rand \& Louda 2004).

a.

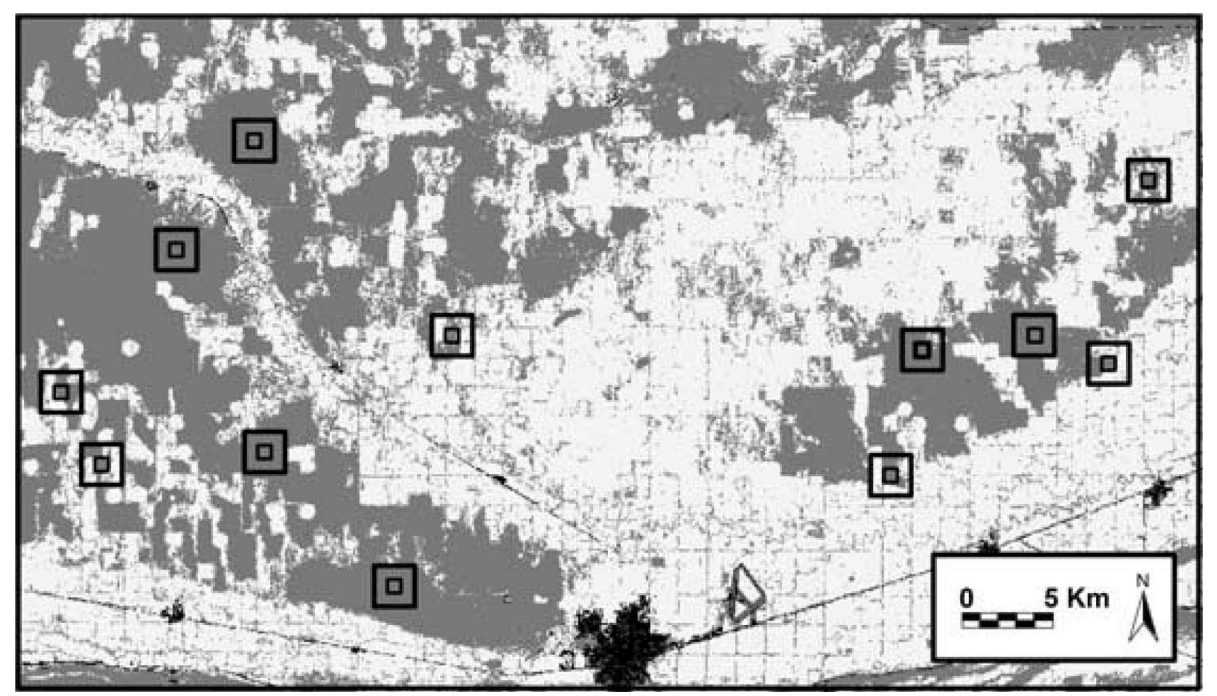

b.

Figure 1. (a) Layout of study sites in central Nebraska (U.S.A.). Light gray areas are crops, dark gray areas are natural habitat, and black areas are urban development and roads. Study sites (64 ha) are indicated by central squares within larger squares that define the area of the surrounding landscape matrix. (b) Layout of each experimental landscape composed of a central grassland site $(800 \times 800 \mathrm{~m})$ and the surrounding landscape matrix, which was either grassland or cropland dominated. The position of the edge and center sampling locations within a site also are indicated.

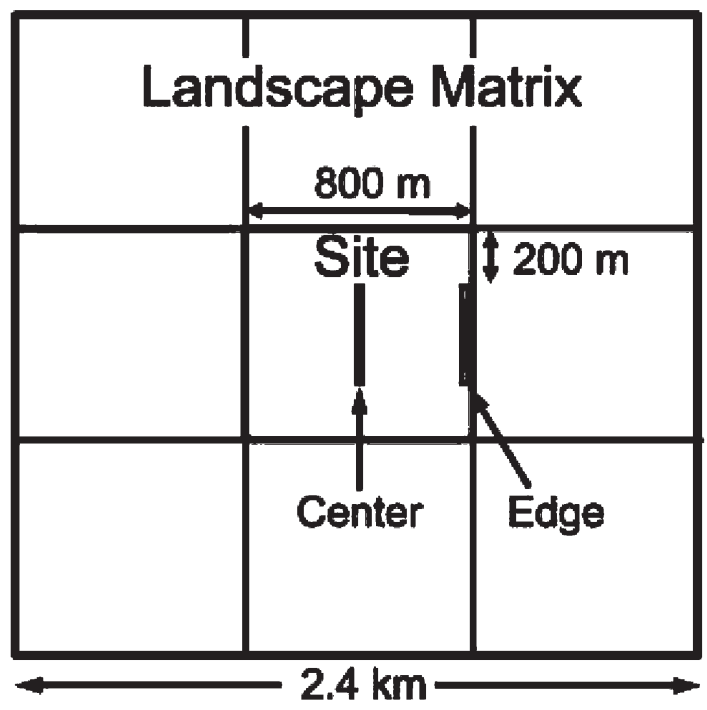


Coccinellid Abundance in Grassland Sites within Different Matrix Types

We used sweep sampling (38-cm-diameter net) to estimate coccinellid abundances within prairie grassland sites embedded within grassland and within cropland matrices. Sampling was carried out between 1000 and 1600 hours on clear to partly cloudy days, when temperatures were $>15^{\circ} \mathrm{C}$, vegetation was dry, and wind speeds were $<24 \mathrm{~km} /$ hour because these factors can affect the efficacy of sweep sampling for coccinellids (Kieckhefer et al. 1992). Samples were collected June 15-30 in 2001, 2002, and 2003 as well as July 15-31 in 2001 and 2002.

Within each grassland site, we sampled at two locations: the center of each site and one edge (Figure 1b). Edges were selected to border row crops in cropland landscape matrices or prairie in the grassland matrices. At the edge location, a 50-sweep sample was taken at each of 12 transects that ran perpendicular to the edge (regularly spaced at 20- to 50-m intervals), starting 200 $\mathrm{m}$ from the corner of the site. Each sample consisted of 25 pendular sweeps of the net along $25 \mathrm{~m}$ running into the site from the edge and another 25 sweeps along 25 $\mathrm{m}$ returning toward the edge along a parallel line $2-4 \mathrm{~m}$ away (50 sweeps $/ 50 \mathrm{~m}$ ). At the center location, sweep sampling was done in exactly the same manner, but transects were initiated $400 \mathrm{~m}$ in from the focal patch edge and again $200 \mathrm{~m}$ from the perpendicular edge (Figure 1b). Net contents of each 50-sweep sample were emptied into a sealable bag and taken to the laboratory, where coccinellids were sorted to species and counted. Coccinellids numbers were summed across samples within locations to generate a single abundance estimate for the edge and center locations at each site.

We used a split-plot analysis of variance to test for effects of landscape matrix type (crop vs. grassland), site (nested within matrix type, random factor), location (edge vs. center), and the matrix type-by-location interaction on June coccinellid abundance (following Donovan et al. 1997). Coccinellid numbers had to be summed across the 3 years for this analysis because low abundances within some categories made it impossible to meet model assumptions when years were treated separately. Cumulative coccinellid abundance was $\ln (x+$ $0.5)$ transformed prior to analysis to normalize distributions and homogenize variances. All statistical analyses were carried out with JMP 4.0.4 (SAS 2001).

We used a two-way mixed model analysis of variance (ANOVA) to examine year-to-year variation in landscape effects on coccinellid abundance. Given low coccinellid abundances in some categories and the fact that there was no significant effect of location on abundance in the above model, for this analysis coccinellid numbers were pooled across locations to generate a single abundance estimate for each site in each year. The ANOVA model included the following effects: landscape matrix type, sampling year (random factor), and their interaction. Coccinellid abundance was once again $\ln (x+0.5)$ transformed prior to analysis to meet model assumptions.

\section{Coccinellid Abundance within Crops versus Grassland}

We also conducted sweep sampling within the crops near each grassland site edge to assess similarities in coccinellid species composition and abundance relative to grasslands. Transects within crops were initiated at the crop edge adjacent to the 12 transects used for grassland edge sweeps. These sampling transects ran into the crop from the fence line. Again, each 50-sweep sample was taken by sweeping $25 \mathrm{~m}$ into the crop and returning along a parallel line (2-4 m away). Crop transects were sampled the same time as grassland transects: 1530 July and August 2001 ( $n=5$ sites) and June 15-30 and July 15-30, 2002 ( $n=6$ sites). Although crop sampling was restricted to within $25 \mathrm{~m}$ of the crop edge, results of previous studies found no consistent effects of distance to field edge on coccinellid abundance in crops (Hoffmann et al. 1997; Udayagiri et al. 1997).

Coccinellid numbers were summed across transects to generate a single abundance estimate in each habitat type (cropland vs. grassland) for each site in each year for analysis. Numbers were pooled across months within years in this case because of low abundances within some month-by-site categories. Paired $t$ tests (one tailed) were then used to test the hypothesis that coccinellid densities were higher in crops than in adjacent grassland habitats in each year.

\section{Coccinellid Abundance at Crop versus Grassland Edges}

In 2002 we used sticky traps to compare coccinellid abundance in aerial samples from the edges of grassland sites embedded within cropland versus those embedded within grassland landscape matrices. Abundances in aerial samples represent an estimate of "potential" beetle colonists at each site. We deployed five traps at the edge of each site within each matrix type on June 1 , July 1, and August 1. Traps were placed along the fence line of the focal edge at 100-m intervals, starting $200 \mathrm{~m}$ from a site corner. Traps consisted of two 25-cm-diameter plates (Styrofoam) coated on one surface with a thin layer of a sticky resin (Tangle-trap insect trap coating, The Tanglefoot Company, Grand Rapids, Michigan). The two plates were attached to opposite sides of a wooden stake and mounted on a fencepost $1.5 \mathrm{~m}$ above the soil surface. Traps were left in the field for 4 weeks.

We summed the number of coccinellid beetles caught on all traps to generate a single-site mean for each month for analysis. A two-way mixed-model ANOVA was used to examine the effects of matrix type, date (random effect), and the date-by-matrix-type interaction on coccinellid abundance ( $n=6$ sites/matrix type). In both 2001 and 2002, the data were transformed $(\ln [x+0.5])$ prior to analysis to meet model assumptions. 


\section{Predator Exclusion Experiment}

To assess whether predatory beetles affect native aphid populations and whether this effect varies with differences in coccinellid abundance in different landscape matrix types, we carried out a short-term predator exclusion experiment. Our model system was a native thistle species, Cirsium flodmanii (Rydb.) Arthur, and a native Cirsium-feeding aphid, Bipersona sp. Aphid abundance peaks in late June, before host plants begin to senesce in mid-to-late July (T.A.R., personal observation). Coccinellid beetles (Coleoptera: Coccinellidae) were the dominant predator group feeding on aphids in our system, although syrphid (Diptera: Syrphidae) and chrysopid (Neuroptera: Chrysopidae) larvae were observed occasionally.

We marked 22 flowering native thistles that did not contain an aphid colony and were at least $5 \mathrm{~m}$ from a conspecific at each of four sites: two within a cropland matrix, two within a grassland matrix. Apterous aphid nymphs, collected from natural populations in the field, were transferred to each tagged thistle plant $(n=20$ per plant) on June 15-16, 2002. Aphids were allowed to settle for 24 hours and then recounted. Additional individuals were added where necessary to ensure a starting density of 20 individuals. Aphids tend to be sessile, thus transferring nonwinged individuals to host plants is an effective method for initiating experimental colonies to assess predator impacts (Hacker \& Bertness 1995; Muller \& Godfray 1999). Experimental aphid colonies were randomly assigned to one of two treatments: a control, which was left untreated, or predator exclusion $(n=11$ replicates/treatment/site). Predators were excluded by enclosing plants within a closed mesh sleeve (approximately $10 \mathrm{~cm}$ diameter $\times 30 \mathrm{~cm}$ long, $0.1-\mathrm{mm}$ mesh), reinforced with wire hoops to minimize contact with plants. Sleeves were placed over the terminal portion of a plant, where aphids typically feed, and the base was fastened to the stem with twist ties, sealing the aphid colony within the sleeve. At two sites, a partial sleevecontrol treatment also was included $(n=11 /$ site). In this treatment, a sleeve of same construction was placed over the plant but left open at the top end. This partial sleeve allowed predator access while simulating potential cage effects. We counted aphid numbers and predators after 5 and 10 days. The experiment spanned an aphid generation, and aphids reproduce parthenogenetically, so colony size at the end reflects population growth (positive or negative) with versus without exposure to predators.

Final aphid densities were power $\left(x^{0.7}\right)$ transformed to meet model assumptions. A standard log transformation of the data was not successful in meeting model assumptions; thus, we used the power transformation that best normalized distributions and homogenized variances. To test for effects of predators on aphid abundance and to examine potential differences between matrix types, we ran a mixed-model ANOVA including the following factors: landscape matrix type, site (nested within matrix type, random), predator exposure treatment (control vs. exclusion), and the matrix type-bypredator treatment and site- (within matrix type) bypredator treatment interactions. To more specifically examine the relationship between coccinellid abundance across experimental sites and predation pressure, we regressed coccinellid numbers, estimated from June sweep samples, on an index of predation intensity calculated using experimental treatments within each site. Predator interaction strength was calculated as the log ratio $\left[\ln \left(N_{P_{+}} / N_{P_{-}}\right)\right]$of mean aphid density on the final census date in the presence $\left(N_{P_{+}}\right)$or absence $\left(N_{P_{-}}\right)$of predators at each site (Shurin et al. 2002).

\section{Results}

Six species of aphidophagous coccinellid beetles occurred in samples from prairie grassland sites over the 3 years. Hippodamia convergens Guérin-Méneville was the most abundant, comprising $46 \%$ of the coccinellids sampled. The other species, in order of relative abundance, were Hippodamia parenthesis (Say) (22\%), Coccinella septempunctata L. (7\%), Coleomegilla maculata (De Geer) (2\%), Cycloneda munda (Say) $(<1 \%)$, and Harmonia axyridis (Pallas) $(<1 \%)$. The four most common species in grasslands were the only species that occurred in the crop samples over 2 years.

\section{Coccinellid Abundance at Sites within Different Matrix Types}

Overall, mean coccinellid abundance, pooled across the 3 years, was five times higher in grassland sites embedded within a cropland landscape matrix than those embedded in a grassland matrix (Figure 2a), producing a significant overall effect of matrix type in the splitplot ANOVA model $\left(F_{1,10}=7.530, p=0.021\right)$. In contrast, there was no significant effect of edge or center location within a site on coccinellid abundance $\left(F_{1,10}=\right.$ $0.114, p=0.742)$. Coccinellid abundance also varied significantly among sites $\left(F_{10,10}=7.851, p=0.002\right)$, but there was no interaction between location and matrix type $\left(F_{1,10}=0.195, p=0.668\right)$. In July, coccinellid abundances were generally low. This was especially pronounced in 2003 when coccinellids were essentially absent from initial July samples, likely due to increasingly important drought conditions, and thus a full sampling protocol was not carried out in that year. However, the general pattern for 2001 and 2002 was consistent with the June data; coccinellids were more than twice as abundant at sites within cropland than within grassland matrices (split-plot ANOVA, effect of matrix type: $F_{1,10}=5.381$, $p=0.043$ ).

Coccinellid abundance varied among years $\left(F_{2,30}\right.$ $=8.719, p=0.001$; Figure 2a). However, the pattern of higher coccinellid abundance at sites within a crop- 
dominated matrix compared with those in a grassland matrix was consistent across all 3 sampling years, resulting in a significant overall effect of matrix type $\left(F_{1,2}=\right.$ $310.668, p=0.003)$ and the lack of a significant year-bymatrix type interaction term $\left(F_{2,30}=0.053, p=0.9489\right)$.

\section{Coccinellid Abundance within Cropland versus Grassland}

Coccinellids were more abundant within cropland edges (corn and soybean) than within adjacent grassland edges in both 2001 and 2002. In 2001 numbers were significantly greater, 3.5-fold, within the cropland edge than within the adjacent grassland edge transects (mean \pm SE: cropland, $1.85 \pm 0.336$; grassland, $0.53 \pm 0.110$; paired $t$ test, $\mathrm{df}=4, t=2.201, p=0.046)$. A similar trend was observed in 2002; coccinellid abundances were 1.6-fold higher in cropland than adjacent grassland (mean \pm SE: cropland, $2.53 \pm 0.416$; grassland, $1.57 \pm 0.260)$, but the difference was not statistically significant (paired $t$ test: $\mathrm{df}=5, t=$ $1.276, p=0.129$ ). Grassland values used in the above comparative analyses were those for sites embedded within an agriculturally dominated landscape matrix, which are likely highly influenced by surrounding cropland habitats. The differences were even greater when contrasting coccinellid abundances within crops to those in grassland sites embedded within grassland-dominated landscape matrices (5.2-fold and 6-fold higher in cropland than grassland in 2001 and 2002, respectively).

\section{Coccinellid Abundance at Crop versus Grassland Edges}

Coccinellid abundances in aerial samples from grassland edges were consistently higher, 2.7- to 9.6-fold across sampling dates, at sites embedded in croplanddominated landscapes than at sites embedded within grassland-dominated landscapes (Figure $2 b$ ). This led to a significant overall effect of matrix type $\left(F_{1,2}=33.474\right.$, $p=0.029$; Figure $2 b$ ). Coccinellid abundance did not vary significantly across sampling dates $\left(F_{2,30}=2.586\right.$; $p=0.279)$, and there was no interaction between matrix type and sampling date $\left(F_{2,30}=1.093 ; p=0.348\right)$.

\section{Predator Exclusion Experiment}

Exposure to predators rapidly reduced densities of the experimental aphid colonies by $48-90 \%$ across sites, resulting in a significant overall effect of the predatorexposure treatment $\left(F_{1,3}=16.629 ; p=0.026\right.$; Figure $\left.2 \mathrm{c}\right)$. This could not be explained only as an artifact of the exclusion sleeves because there were no significant differences between aphid densities in the partial-sleeve control and the open-control treatments (mean \pm SE: open control, $7.81 \pm 2.27$; partial cage control, $7.73 \pm 2.85$; mixed model ANOVA, effect of treatment: $F_{1,1}=0.572$, $p=0.587$ ).

In contrast to the predator treatment, neither landscape matrix type $\left(F_{1,2}=0.129 ; p=0.745\right)$, site $\left(F_{2,72}=\right.$ $1.001 ; p=0.465)$, nor the predator treatment-by-site
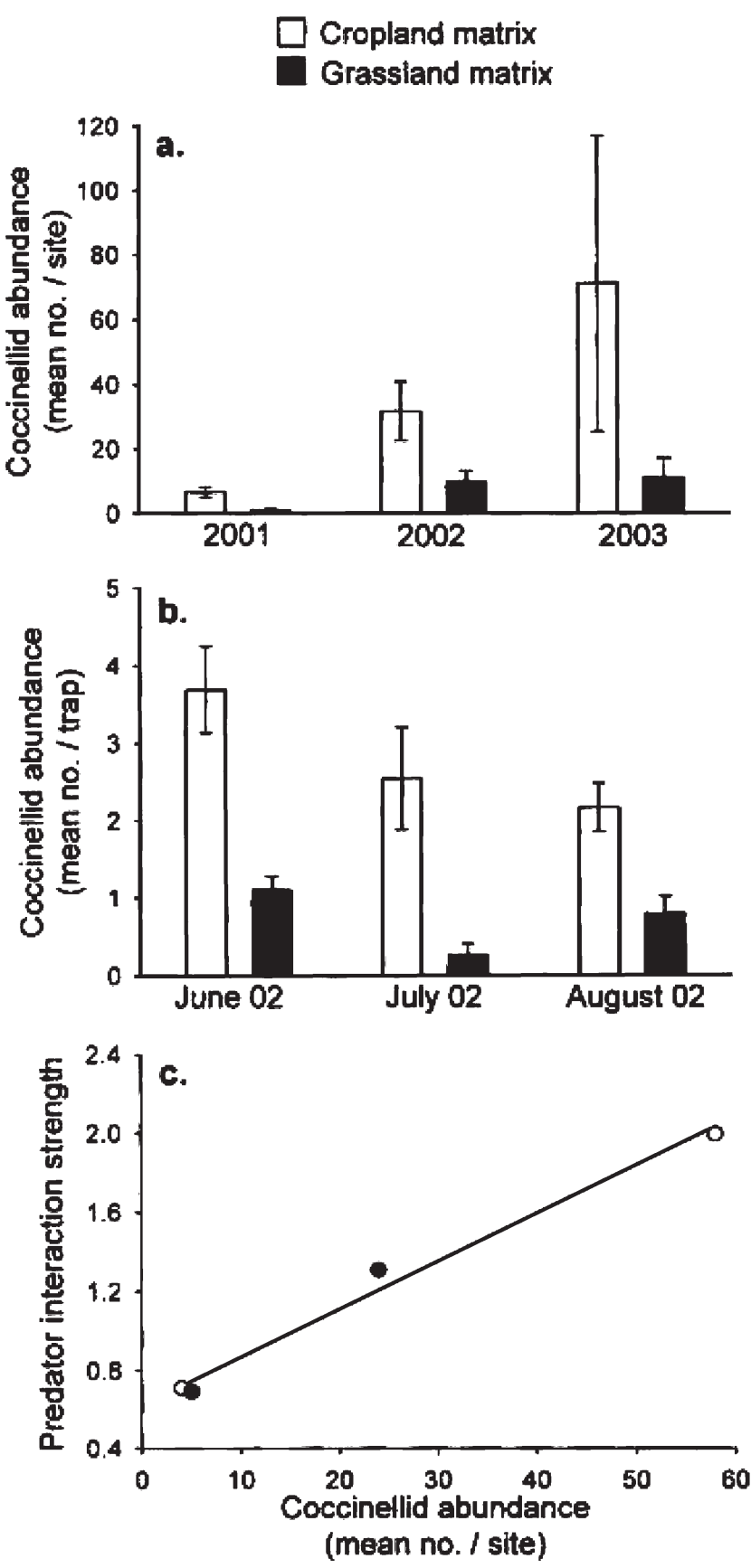

Figure 2. (a) Coccinellid abundance in June sweep samples from grassland remnants in relation to landscape matrix type in each year. Bars represent the untransformed mean $( \pm 1 \mathrm{SE})$ number of coccinellids sampled per site in each year $(n=6$ sites/matrix type). (b) Coccinellid abundance in aerial samples at site edges adjacent to grassland versus cropland landscape matrices over three sampling dates in 2002. Data are the untransformed mean $( \pm 1 \mathrm{SE})$ number of coccinellids per trap $(n=6$ sites per matrix type; site estimates based on 5 traps/site). (c) Relationship between predation pressure on experimental aphid colonies and coccinellid abundance at each of the four experimental sites in 2002. Plotted is the absolute value of the interaction strength (log ratio), $\mid \ln \left(N_{P_{+}} /\right.$ $\left.N_{P-}\right)$ |, where $\mathrm{N}$ is the mean aphid density in the presence $(P+)$ or absence $(P-)$ of predators at each site as a function of coccinellid abundance in June. 
interaction $\left(F_{3,72}=0.257 ; p=0.856\right)$ had a significant effect on final aphid density. Unexpectedly, the interaction of predator treatment-by-matrix type also was not significant $\left(F_{1,3}=0.300 ; p=0.622\right)$, which contrasted with the expectation based on observational data. However, coccinellid abundance was uncharacteristically low at one experimental site within a cropland matrix and uncharacteristically high at one experimental site within a grassland matrix (Figures 2a \& 2c). Consequently, the abundance of coccinellids within experimental sites did not reflect the broader pattern (i.e., coccinellids were not consistently higher in cropland compared with grassland matrices [Figure 2c]). Thus a sample size effect (n $=2$ sites (matrix type) likely obscured the predicted matrix effect. However, regression analysis, specifically examining the relationship between site-level coccinellid abundance and predation pressure, showed that the strength of the negative effect of predators at each site was strongly related to increasing coccinellid abundance in June (regression results: $y=-0.626-0.024 x ; R_{\text {adj }}^{2}=$ $0.98, F_{1,2}=153.216, p<0.007$; Figure 2c).

\section{Discussion}

Overall, high crop cover in the surrounding landscape matrix resulted in a substantial increase in the abundance of generalist coccinellid predators within the embedded grassland study sites. Furthermore, predation pressure on a focal native aphid herbivore was strongly related to coccinellid abundance. These results suggest that habitat loss to agriculture likely increases consumer pressure on native herbivores within nearby natural habitat remnants due to spillover of generalist predators from the surrounding cropland landscape matrix.

\section{Matrix Influences on Predator Abundance}

The influx of species from the surrounding landscape matrix can be an important factor influencing species abundance and diversity in terrestrial habitat islands, potentially even obscuring patterns predicted from traditional island biogeographic models (Ås 1999; Cook et al. 2002). Such matrix spillover, for instance, likely underlies the inverse abundance-area relationship often observed for generalist species in fragmentation studies (Debinski \& Holt 2000). Previous work suggests that this can be an important factor driving patterns in insect communities. For example, Steffan-Dewenter and Tscharntke (2000) found that densities of polyphagous butterfly species increase with decreases in the area of calcareous grassland fragments, presumably due to the accumulation of individuals from the surrounding agricultural matrix. Similarly, Suarez et al. (1998) found that abundances of the invasive Argentine ant (Linepithema humile) are much higher at edges of coastal-scrub fragments near developed urban habitats. Our data similarly indicate that the surrounding landscape matrix can strongly influence patterns of insect predator abundance in remaining prairie grassland remnants. Across the 3 years of our study, coccinellids were consistently more abundant, by three- to sixfold, in grassland sites embedded within a crop-dominated landscape matrix compared with those within a grassland matrix.

This pattern theoretically could reflect a number of underlying mechanisms. First, direct behavioral responses of beetles to habitat edges could result in their aggregation, and thus higher abundances there. However, such edge-mediated behavioral responses can be excluded as a driving mechanism in our study because we found no differences in beetle abundance at grassland edges compared to grassland centers. A second possibility is that coccinellid beetles were responding to aphid prey which themselves spill over from high-density sources in cropping systems into adjacent grassland sites. Although conceivable, this is unlikely in this system for two reasons. First, grass-feeding aphids, which could potentially be shared with related crops, were never observed while carrying out vegetation or insect sampling in prairie over the course of the study (T.A.R, unpublished data). Second, aphid numbers in June likely reflect population buildup by parthenogenesis, rather than dispersal processes known to be important for larger, more vagile, species like coccinellid beetles. Thus, the higher overall abundance of coccinellids in grassland sites within cropland-dominated landscapes more likely reflects the spillover of coccinellid beetles themselves.

Three lines of evidence support this hypothesis. First, we found substantial overlap in coccinellid species composition between cropland and grassland habitats. The four species sampled from crops were also the most abundant species within grassland systems, indicating that the common coccinellids are true habitat generalists.

Second, coccinellids were consistently more abundant within the crop edges than within the edges of the adjacent grasslands, suggesting that crops generally harbor higher relative densities of these predators. Results of previous studies in the central United States similarly show that coccinellids make up a dominant component of the predator community within cropping systems (Kieckhefer et al. 1992). Furthermore, densities are often higher within crops (maize, soybean, or alfalfa) than within more natural, successional grassland systems or seminatural field margins during the productive summer months (Maredia et al. 1992; Hoffman et al. 1997).

Third, throughout the summer, coccinellids were 2.7 to 9.6 times more abundant in aerial samples from the edges of grassland sites embedded within a cropland than in a grassland matrix. This further suggests that croplanddominated landscapes support higher densities of mobile coccinellid colonists than do homogeneous grassland areas. The importance of crops as potential sources of insect predators has been similarly noted by Duelli et al. (1990), who estimated a seasonal production of 6000 adult coc- 
cinellid beetles from a single 1-ha maize field and documented a mass net emigration of beetles into adjacent habitats as within-crop aphid populations declined. Thus we conclude that the most parsimonious explanation for the strong and consistent pattern of higher coccinellid abundance in grassland sites embedded within cropversus grassland-dominated landscapes in our study is that beetles respond numerically to high prey availability within cropping systems and then spillover into adjacent natural habitats. Overall, our results reinforce the inference based on previous work that cropping systems can support relatively high densities of mobile coccinellid predators and, thus, may serve as important sources of insect predators spilling over into adjacent systems.

Theory predicts that the direction of spillover effects will be from high to low productivity habitats (Oksanen 1990; Holt \& Hochberg 2001). In our system, relatively arid natural habitat patches are juxtaposed with a highly productive cropland matrix. This would be predicted to result in the asymmetrical flow of mobile predators from the matrix into recipient natural habitats, generating patterns consistent with those we observed in this study. Such dynamics are likely to be common in modern agricultural landscapes, which are typified by highly productive, fertilized, and irrigated monocultures in which pest outbreaks represent high-quality, but ephemerally available, resources for predators. Alternately, however, when patches are embedded within a low-quality or hostile matrix, generalist predators may respond in a manner similar to that predicted for specialists; for example, they may exhibit reduced abundance and control over prey populations in more fragmented systems (Kareiva 1987).

Because spillover is a spatially explicit process, effects are expected to be more prevalent along patch edges and in small habitat patches (Cook et al. 2002). Surprisingly, we found no significant differences between coccinellid abundance at the edge and center ( $>200 \mathrm{~m}$ from crop) of grassland sites embedded within cropland matrices. The lack of an edge effect may reflect the relatively high vagility of coccinellids (see Elliott et al. 1998), which likely allowed them to disperse throughout grassland sites that were embedded in cropland matrices. Thus, even these relatively large (64 ha) grassland areas appear to have been effectively "all edge." Sites within a grassland matrix, where coccinellid abundances were extremely low, were at least $800 \mathrm{~m}$ from extensive cropping systems. Thus, they were effectively buffered by the surrounding grassland matrix. In contrast, sites within a cropland matrix bordered crop fields on multiple edges.

In general, these results suggest that for relatively mobile species, such as coccinellids, the scale over which spillover edge effects can be detected (i.e., the depth of edge influence) is likely to be greater than that typically reported for insects (up to $100 \mathrm{~m}$; reviewed in Ries et al. 2004). In fact, for prairie preserves embedded within ag- ricultural landscape mosaics, our data suggest that core habitat would have to be $>400 \mathrm{~m}$ from a cropland edge to minimize potential matrix influence resulting from the influx of mobile species. Our findings are consistent with the results of previous work demonstrating that coccinellids often respond to landscape structure at scales of $>1 \mathrm{~km}$ (Elliott et al. 1998) and suggest that coccinellids may link the dynamics of natural and cropland landscape elements over relatively large spatial extents.

\section{Implications for Predator-Prey Dynamics in Natural Habitat Remnants}

Despite a long tradition of studies quantifying the effects of habitat loss on species diversity and abundance, comparatively few field studies have examined the potential effects on functional interactions between species (Didham et al. 1996; Debinski \& Holt 2000). Yet, such mechanistic studies will be important in ultimately predicting species responses to environmental change (Kareiva et al. 1993; McGeoch \& Gaston 2000). Documenting shifts in the abundance of potential antagonists alone does not necessarily imply a corresponding change in ecological interaction intensities. Thus, researchers stress the importance of combining abundance data with direct studies of predator impact on populations of interest (Andow \& Risch 1985). We found that predators severely reduced (by $48-90 \%$ ) populations of a focal native aphid, Bipersona sp., which occurs on native thistles in the genus Cirsium. Coccinellids were the dominant predator group attacking Bipersona, accounting for over $90 \%$ of all predators observed on experimental plants. Contrary to expectation, the effect of predators in the experiment was not higher in grassland sites embedded within cropland matrices. However, as expected, predation intensity increased strongly with increased coccinellid abundance at a given site (Figure 2c). This suggests that coccinellids were an important determinant of predation pressure and that variation in predator abundance across experimental sites was sufficient to drive considerable differences in predator impact on native aphid herbivores, at least over the short-term scale investigated.

In combination, the pattern of consistently higher coccinellid abundance at grassland sites embedded within cropland landscapes, documented over 3 years, and the strong relationship between coccinellid abundance and predation pressure, documented in the exclusion experiment, suggest that the native aphids likely experience increased consumer pressure with increasing levels of habitat loss to agriculture. Furthermore, theoretical work suggests that spillover of shared predators from alternative habitats can have particularly strong top-down effects on resident prey in recipient habitats when: (1) source habitats are more productive than recipient habitats, (2) the prey in the recipient habitat are strongly attacked, (3) predator movement rates are substantial, and (4) predator mortality rates in the recipient 
habitat are low (Holt \& Hochberg 2001). The first two conditions are met in our system because crops are generally more productive than arid grasslands, and results of the predator-exclusion experiment suggest that aphid prey are strongly attacked by predators. Additionally, the significant numbers of individuals caught in aerial samples and the fact that coccinellids are highly vagile (often responding to landscape structure over large spatial extents; Elliott et al. 1998) are consistent with the third condition. Thus, our system contains at least three of the four conditions theoretically predicted to result in strong effects of spillover predation on recipient herbivore communities.

To our knowledge, our study is among the first to investigate the potential importance of spillover of generalist predators from the surrounding cropland matrix on insect community dynamics within remaining natural areas. However, similar effects for herbivorous insects have been suggested by McKone et al. (2001). They found that adult corn-rootworm beetles (Diabrotica spp.), which feed as larvae in corn fields early in the growing season, spill over in large numbers into adjacent tall-grass prairie causing increased damage to native plants growing near the prairie fragment edge. Our results combined with those of McKone et al. (2001) suggest that the spillover of agriculturally subsidized insects can magnify insect consumer-resource interactions and thus pose a potential threat to native prey populations in remaining areas of natural habitat. Our results also complement work demonstrating that cross-system fluxes of subsidized mobile consumers can play an important role in linking dynamics across natural habitat interfaces (e.g., marine and terrestrial and aquatic and terrestrial; Polis \& Hurd 1995; Polis et al. 1997; Polis et al. 2004) by suggesting that such fluxes are likely to be similarly important across agricultural-to-natural landscape interfaces.

Theory suggests that habitat loss and isolation will result in the differential loss of top predator species (Holt et al. 1999), thereby potentially reducing top-down control of prey populations in fragmented habitats. This prediction is supported by a number of empirical studies in both vertebrate (Terborgh et al. 2001) and invertebrate communities (reviewed in van Nouhuys 2005). However, if the spillover of effective generalist predators turns out to be an important phenomenon, as suggested by our results, then landscape changes related to habitat conversion may result in an increase, rather than a decrease, in consumer pressure on herbivores in natural habitat remnants. The impacts of habitat loss on natural enemy-prey dynamics will depend on the combined effects of the loss of specialist species resulting from isolation and area effects and any enhancement of generalist species due to matrix-mediated spillover effects. Cook et al. (2002) suggest that when applied to terrestrial habitat islands, biogeography theory should be refined to make allowances for matrix spillover or "the colonization of 'islands' from the 'sea." Consideration of such spillover effects likely will be similarly critical in understanding the consequences of habitat loss for trophic interactions in terrestrial habitat remnants.

\section{Acknowledgments}

We are grateful to the numerous individuals who generously granted us permission to work on their property, with particular thanks to J. Martin. H. Ozawa, S. Hawkins, and L. Young provided invaluable assistance in the field and laboratory. Comments from R. Holt, J. Memmott, T. Minchinton, C. Thies, T. Tscharntke, and two anonymous reviewers for Conservation Biology greatly improved the manuscript. This research was funded by a D.H. Smith Postdoctoral Research Fellowship to T.A.R. Support for T.A.R. while writing the manuscript was provided by an Alexander von Humboldt Research Fellowship. This is publication DHS2006-06 of the D.H. Smith Fellowship Program.

\section{Literature Cited}

Andow, D. A., S. J. Risch. 1985. Predation in diversified agroecosystems: relations between a coccinellid predator, Coleomegilla maculata, and its food. Journal of Applied Ecology 22 :357-372.

Ås, S. 1999. Invasion of matrix species in small habitat patches. Conservation Ecology 3 : http://www.consecol. org/vol3/iss1/art1/

Cook, W. C., K. T. Lane, B. L. Foster, R. D. Holt. 2002. Island theory, matrix effects and species richness patterns in habitat fragments. Ecology Letters $5: 619-623$.

Debinski, D. M., R. D. Holt. 2000. A survey and overview of habitat fragmentation experiments. Conservation Biology 14 :342-355.

Didham, R. K., J. Ghazoul, N. E. Stork, A. J. Davis. 1996. Insects in fragmented forests: a functional approach. Trends in Ecology \& Evolution $11: 255-260$.

Donovan, T. M., P. W. Jones, E. M. Annand, F. R. Thompson III. 1997. Variation in local-scale edge effects: mechanisms and landscape context. Ecology 78 :2064-2075.

Duelli, P., M. Studer, I. Marchand, S. Jakob. 1990. Population movements of arthropods between natural and cultivated areas. Biological Conservation 54 :193-207.

Ekbom, B., M. E. Irvin, Y. Robert. 2000. Interchanges of insects between agricultural and surrounding landscapes. Kluwer Academic Publishers, Dordrecht, The Netherlands.

Elliott, N. C., R. W. Kieckhefer, J. H. Lee, B. W. French. 1998. Influence of within-field and landscape factors on aphid predator populations in wheat. Landscape Ecology 14 :239-252.

ESRI (Environmental Systems Research Institute). 1999. ArcView GIS 3.2. ESRI, Redlands, California.

Fagan, W. F., R. S. Cantrell, C. Cosner. 1999. How habitat edges change species interactions. The American Naturalist 153 :165-182.

Hacker, S. D., M. D. Bertness. 1995. A herbivore paradox: Why salt-marsh aphids live on poor-quality plants. The American Naturalist $145: 192-210$.

Hoffmann, M. P., M. S. Orfanedes, L. H. Pedersen, J. J. Kirkwyland, E. R. Hoebeke, R. Ayyappath. 1997. Survey of lady beetles (Coleoptera: Coccinellidae) in sweet corn using yellow sticky cards. Journal of Entomological Science 32 :358-369. 
Holt, R. D. 1996. Food webs in space: an island biogegraphic perspective. Pages 313-323 in K. Winemiller, editor. Food webs: contemporary perspectives. Chapman \& Hall, London.

Holt, R. D., J. H. Lawton, G. A. Polis, N. D. Martinez. 1999. Trophic rank and the species-area relationship. Ecology $80: 1495-1504$.

Holt, R. D., M. E. Hochberg. 2001. Indirect interactions, community modules and biological control: a theoretical perspective. Pages 13-37 in E. Wajnberg, J. K. Scott P. C. Quimby, editors. Evaluating indirect ecological effects of biological control. CAB International, Wallingford, United Kingdom.

Janzen, D. H. 1983. No park is an island: increase interference from outside as park size decreases. Oikos 41 :402-410.

Janzen, D. H. 1986. The eternal external threat. Pages 286-303 in M. E. Soule, editor. Conservation biology: the science of scarcity and diversity. Sinauer, Sunderland, Massachusetts.

Jules, E. S., P. Shahani. 2003. A broader ecological context to habitat fragmentation: why matrix habitat is more important than we thought. Journal of Vegetation Science 14 :459-464.

Kareiva, P. M. 1987. Habitat fragmentation and the stability of predator-prey interactions. Nature $326: 388-390$.

Kareiva, P. M., J. G. Kingsolver, R. B. Huey. 1993. Biotic interactions and global change. Sinauer, Sunderland, Massachusetts.

Kieckhefer, R. W., N. C. Elliott, D. A. Beck. 1992. Aphidophagous coccinellids in alfalfa, small grains, and maize in eastern South Dakota. The Great Lakes Entomologist 25 :15-23.

Kruess, A., T. Tscharntke. 1994. Habitat fragmentation, species loss, and biological control. Science 264 :1581-1584.

Landis, D. A., S. D. Wratten, G. M. Gurr. 2000. Habitat management to conserve natural enemies of arthropod pests in agriculture. Annual Review of Entomology 45 :175-201.

Lawton, J. H. 1995. Population dynamic principles in R. M. May, editor. Extinction risks. Oxford University Press, Oxford, United Kingdom.

Levins, R. 1970. Extinction. Pages 75-107 in M. Gerstenhaber, editor. Some mathematical questions in biology. Lectures on mathematics in the life sciences. American Mathematical Society, Providence, Rhode Island.

MacArthur, R. H., E. O. Wilson. 1967. The theory of island biogeography. Princeton University Press, Princeton, New Jersey.

Maredia, K. M., S. H. Gage, D. A. Landis, J. M. Scriber. 1992. Habitat use patterns by the seven-spotted lady beetle (Coleoptera: Coccinellidae) in a diverse agricultural landscape. Biological Control $2: 159-165$.

McGeoch, M. A., K. J. Gaston. 2000. Edge effects of the prevalence and mortality factors of Phytomyza ilicis (Diptera, Agromyzidae) in a suburban woodland. Ecology Letters $3: 23-29$.

McKone, M., K. K. McLauchlan, E. G. Lebrun, A. C. McCall. 2001. An edge effect caused by adult corn-rootworm beetles on sunflowers in tallgrass prairie remnants. Conservation Biology 15 :1315-1324.

Muller, C. B., H. C. J. Godfray. 1999. Predators and mutualists influence the exclusion of aphid species from natural communities. Oecologia $119: 120-125$.

Oksanen, T. 1990. Exploitation ecosystems in heterogeneous habitat complexes. Evolutionary Ecology $4: 220-234$.

Paton, P. W. C. 1994. The effect of edge on avian nest success: how strong is the evidence. Conservation Biology 8 :17-26.

Pimm, S. L. 1991. The balance of nature? Ecological issues in the conservation of populations and communities. Chicago University Press, Chicago.

Polis, G. A., W. B. Anderson, R. D. Holt. 1997. Toward an integration of landscape and food web ecology: the dynamics of spatially subsidized food webs. Annual Review of Ecology and Systematics $28: 289-316$.
Polis, G. A., S. D. Hurd. 1995. Extraordinarily high spider densities on islands: flow of energy from the marine to terrestrial food webs and the absence of predation. Proceedings of the National Academy of Sciences of the United States of America 92 :4382-4386.

Polis, G. A., M. E. Power, G. R. Huxel. 2004. Food webs at the landscape level. University of Chicago Press, Chicago.

Rand, T. A., S. M. Louda. 2004. Exotic weed invasion increases the susceptibility of native plants to attack by a biocontrol herbivore. Ecology 85 :1548-1554.

Ries, L., R. J. Fletcher, J. Battin, T. D. Sisk. 2004. Ecological responses to habitat edges: mechanisms, models, and variability explained. Annual Review of Ecology and Systematics 35 :491-522.

Roland, J., P. D. Taylor. 1997. Insect parasitoid species respond to forest structure at different spatial scales. Nature $386: 710-713$.

SAS. 2001. JMP 4.0.4. SAS Institute, Cary, North Carolina.

Saunders, D. A., R. J. Hobbs, C. R. Margules. 1991. Biological consequences of ecosystem fragmentation: a review. Conservation Biology 5 :18-32.

Schneider, M. F. 2001. Habitat loss, fragmentation and predator impact: spatial implications for prey conservation. Journal of Applied Ecology $38: 720-735$.

Shurin, J. B., E. T. Borer, E. W. Seabloom, K. Anderson, C. A. Blanchette, B. Broitman, S. D. Cooper, B. S. Halpern. 2002. A cross-ecosystem comparison of the strength of trophic cascades. Ecology Letters $5: 785-791$.

Soulé, M. E. 1986. Conservation biology. Sinauer Associates, Sunderland, Massachusetts.

Steffan-Dewenter, I., T. Tscharntke. 2000. Butterfly community structure in fragmented habitats. Ecology Letters $3: 449-456$.

Suarez, A. W., D. T. Bolger, T. J. Case. 1998. Effects of fragmentation and invasion on native ant communities in coastal southern California. Ecology 79 :2014-2056.

Terborgh, J., et al.. 2001. Ecological meltdown in predator-free forest fragments. Science $294: 1923-1926$.

Thies, C., T. Tscharntke. 1999. Landscape structure and biological control of agroecosystems. Science 285 :893-895.

Tscharntke, T., A. Kruess. 1999. Habitat fragmentation and biological control. In H. V. Cornell, editor. Theoretical approaches to biological control. Cambridge University Press, Cambridge, United Kingdom.

Tscharntke, T., I. Steffan-Dewenter, A. Kruess, C. Thies. 2002. Contribution of small habitat fragments to conservation of insect communities of grassland-cropland landscapes. Ecological Applications $12: 354-363$.

Udayagiri, S., C. E. Mason, J. D. Pesek. 1997. Coleomegilla maculata, Coccinella septempunctata (Coleoptera: Coccinellidae), Chrysoperla carnea (Neuroptera: Chrysopidae), and Macrocentrus grandii (Hymenoptera: Braconidae) trapped on colored sticky traps in corn habitats. Environmental Entomology 26 :983-988.

U.S. Geological Survey (USGS). 2000. Nebraska Land Cover Data Set. 1st edition. U.S. Geological Survey, Sioux Falls, South Dakota.

Vandermeer, J., R. Carvajal. 2001. Metapopulation dynamics and the quality of the matrix. The American Naturalist 158 :211-220

van Nouhuys, S. 2005. Effects of habitat fragmentation at different trophic level in insect communities. Annales Zoologici Fennici 42 :433-447. 